\title{
Electrochemical Reactions at Sacrificial Electrodes: Electrochemical Synthesis of Aluminium(III) Alkoxides and their Coordination Compounds.
}

\author{
Baljit Singh*, Kanchan Bala, Kishanpal Singh and Sukhveer Singh \\ Department of Chemistry, Punjabi University, Patiala-147002, Punjab, India. \\ E-mail: baljit_chemz@yahoo.co.in; Kanchan_2986@yahoo.com; \\ Kishanpal.3112@gmail.com; Sukhveer74@yahoo.com
}

\begin{abstract}
Electrochemical reactions of methanol, ethanol, propan-l-ol, butan-1-ol, pentan-1-ol, hexan-1-ol, heptan-1-ol, octan-1-ol, nonan-1-ol and decan-1-ol (ROH) at sacrificial aluminium anode and inert platinum cathode in the presence of tetrabutylammonium chloride as a conductive additive and acetonitrile as solvent yield aluminium(III) alkoxides. On refluxing with ligand $(L)$ \{where $L=2,2$ '-bipyridyl and 1,10-phenanthroline these alkoxides don't form coordination compounds. However, the coordination compounds have been prepared by electrolyzing the solution of above alcohols in the presence of ligand $(L)$ at aluminium anode. These products have been characterized by microanalysis, physical measurements and IR spectral studies.General formula conform to $M(O R)_{3}$ and $M(O R)_{3}$.L. $\{$ where $M-A l u m i n i u m$ and $L-$ ligand\}.All these reactions proceed with high current efficiencies.
\end{abstract}

Keywords: Electrochemical reactions; Sacrificial Electrode; Aluminium(III) alkoxides.

\section{Council for Innovative Research}

Peer Review Research Publishing System

\section{Journal: Journal of Advances in Chemistry}

Vol. 5, No. 1

editor@cirworld.com

www.cirworld.com, member.cirworld.com 


\section{Introduction}

Electrochemical synthetic technique is one of the challenging techniques to this technological world. In the present era, this technique has become backbone for chemical sciences and attracted a great deal of attention because of their synthetic utility in organic[1], inorganic[2], green, nanochemistry[3], metal deposition, chemical and pharmaceutical industries[4], thin film solar cells[5] etc. These alkoxides have served as an excellent catalysts[6] in several organic reactions. The continuous interest of our laboratory in electrochemical synthesis of inorganic compounds on different metals like mercury, cadmium, zinc, antimony, copper and bismuth[7-13], we herein, wish to report the synthesis of aluminium(III) alkoxides and their coordination compounds with 2,2'-bipyridyl and 1,10-phenanthroline. Direct electrochemical method has a great promise for direct conversion of less electropositive metal to their alkoxides owing to its simplicity and high productivity [14] as well as its non-polluting character.

Experimental: Acetonitrile was kept over 4A molecular sieves for 24 hours and then double distilled. Freshly distilled acetonitrile was used as a solvent. Tetrabutylammonium chloride was crystallized from conductivity water and dried under reduced pressure at $100^{\circ} \mathrm{C}$. Alcohols were purified by the usual methods[15]. Electrolysis of the solution of 3 $\mathrm{mL}$ of alcohol $(\mathrm{ROH})$ in acetonitrile $(250 \mathrm{~mL})$ containing tetrabutylammonium chloride $(1.0 \mathrm{~g})$ was carried out in $\mathrm{H}$-Type cell. Aluminium plate $(2 \times 10 \times 0.02 \mathrm{~cm} 3)$ was dipped in anode compartment and platinum foil $(1.0 \times 1.0 \mathrm{~cm} 2)$ in cathode compartment. Outlets were sealed after fitting the guard tubes. Necessary connections were made with Toshniwal electrophoresis power supply and potential across the electrodes was then adjusted so that a current of $20 \mathrm{~mA}$ passed through the solution. The electrolytic solution was stirred efficiently using magnetic stirrer.The cell can be represented as:

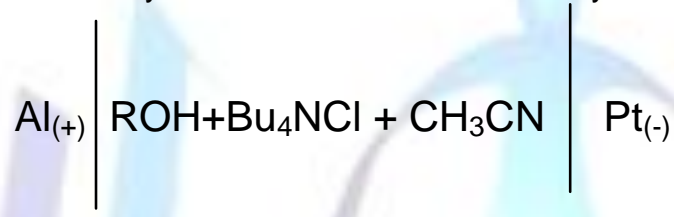

Where $\mathrm{Al}_{(+)}$is Aluminium anode, $\mathrm{Pt}_{(-)}$is platinum cathode, $\mathrm{Bu}_{4} \mathrm{NCl}$ is tetrabutylammonium chloride (supporting electrolyte) and $\mathrm{ROH}$ is alcohol used in the system.

Electrolysis was conducted for 10 hours at a constant current of $20 \mathrm{~mA}$. Solid product separated in the anode compartment was filtered, washed with hot acetonitrile, dry ether and then dried under vacuum. All efforts were made to protect the products from air and moisture. In order to synthesize the coordination compounds of these products, $1.0 \mathrm{~g}$ of ligand (2,2'-bipyridyl or 1,10- phenanthroline) was also added in addition to the above substrates before starting the electrolysis. The other details are same as discussed above.

Melting points of all these compounds were determined using electrical device with a heating rate of $5^{\circ} \mathrm{C}$ per minute. Aluminium contents in these compounds were determined using oxine method[15].Carbon, hydrogen and nitrogen (where applicable) contents in the products were determined through 'Elementor vario EL' CHNS Elemental analyzer.

Infra red spectra of the products have been recorded on Perkin- Elmer spectrophotometer (FTIR) in the region of 4000 $400 \mathrm{~cm}^{-1}$ using $\mathrm{KBr}$ pallets.

The current efficiencies[16] (gram equivalents of metal dissolved per Faraday of electricity passed) of all these reactions were determined using Faraday's first law of electrolysis by electrolyzing the above systems for exactly two hours at a constant current of $20 \mathrm{~mA}$.

\section{Results and Discussion:}

\section{(a) Aluminium (III) Alkoxides:}

Electrochemical reactions of alcohols at sacrificial aluminium anode and inert platinum cathode yield aluminium (III) alkoxides. The mechanism of the reaction is as given:

$\begin{array}{ll}\text { At Inert Platinum cathode: } & 3 \mathrm{ROH}+3 \mathrm{e}^{-} \longrightarrow 3 \mathrm{RO}^{-}+3 / 2 \mathrm{H}_{2} \\ \text { At Sacrificial Aluminium anode: } \quad 3 \mathrm{RO}^{-}+\mathrm{Al}_{(+)} \longrightarrow \mathrm{Al}(\mathrm{OR})_{3}+3 \mathrm{e}^{-}\end{array}$

Melting points of all these products have been determined.It has been observed that these products do not melt upto $300^{\circ} \mathrm{C}$ but decompose in the range between $200^{\circ} \mathrm{C}$ to $250^{\circ} \mathrm{C}$. The decomposition of products is indicated from the change in colour of these compounds. Solubility of all these compounds has been determined in various commonly used organic solvents like chloroform, carbon tetrachloride, benzene, N,N'-dimethyl formamide, methanol, acetone, dimethyl sulphoxide and pyridine. All these compounds are insoluble in these solvents. The electrolysis characteristics of these systems are recorded in Table-1. Aluminium contents in these compounds (determined by oxine method) correspond to $3: 1$ stoichiometry of alcohol and aluminium. Microanalysis for carbon, hydrogen and all the analytical data conform to molecular formula $\mathrm{Al}(\mathrm{OR})_{3}$. The relevant data are summarized in Table- 1. Infrared spectral data of the products reveal that there is no absorption band in the range of $3600-3200 \mathrm{~cm}^{-1}$ corresponding to the hydroxyl group of alcohol which shows that the product is completely free from alcohol.

Various workers have reported[17-21] $\mathrm{v}(\mathrm{C}-\mathrm{O}) \mathrm{M}$ and $\mathrm{v}(\mathrm{M}-\mathrm{O})$ stretching modes in the metal alkoxides in the region of $1160-1000 \mathrm{~cm}^{-1}$ and $600-400 \mathrm{~cm}^{-1}$ respectively. In the present studies, the characteristic bands of all the products appeared in the region of $1130-967 \mathrm{~cm}^{-1}$ and $590-450 \mathrm{~cm}^{-1}$. Thus the absorption bands present in the region of $590-450$ 
$\mathrm{cm}^{-1}$ may be assigned to $\mathrm{v}(\mathrm{Al}-\mathrm{O})$ stretching vibrations. Presence of these bands and absence of bands due to hydroxyl group in the electrochemical products indicate that the hydrogen of the alcohol has been replaced by anodic aluminium. Absorption bands present in the region of $1130-967 \mathrm{~cm}^{-1}$ may be assigned to $\mathrm{v}(\mathrm{C}-\mathrm{O}) \mathrm{Al}$ stretching vibrations. It has been reported[17-21] that infrared data of metal alkoxides show existence of two types of v(C-O)M absorption bands. In general, terminal alkoxide groups show absorption bands in the region of $1170-1040 \mathrm{~cm}^{-1}$ and bridged alkoxide groups show absorption in the region of $1040-950 \mathrm{~cm}^{-1}$.Infrared spectra of the present electrochemical products show the appearance of two/three absorption bands in the region of 1030-967 $\mathrm{cm}^{-1}$. So, the appearance of broad bands in the lower region due to $\mathrm{v}(\mathrm{C}-\mathrm{O}) \mathrm{Al}$ indicate the polymeric structure of these products through alkoxy bridging. The appearance of $\mathrm{v}(\mathrm{C}-\mathrm{O}) \mathrm{Al}$ absorption band in the region of $1130-1040 \mathrm{~cm}^{-1}$ are assigned to terminal alkoxide groups.

High melting point, insoluble behaviour of the products in various organic solvents and the stronger bands in the lower region due to $\mathrm{v}(\mathrm{C}-\mathrm{O}) \mathrm{Al}$ support the polymeric nature of aluminium alkoxides. The plausible structure of these aluminium(III) alkoxides is given below:

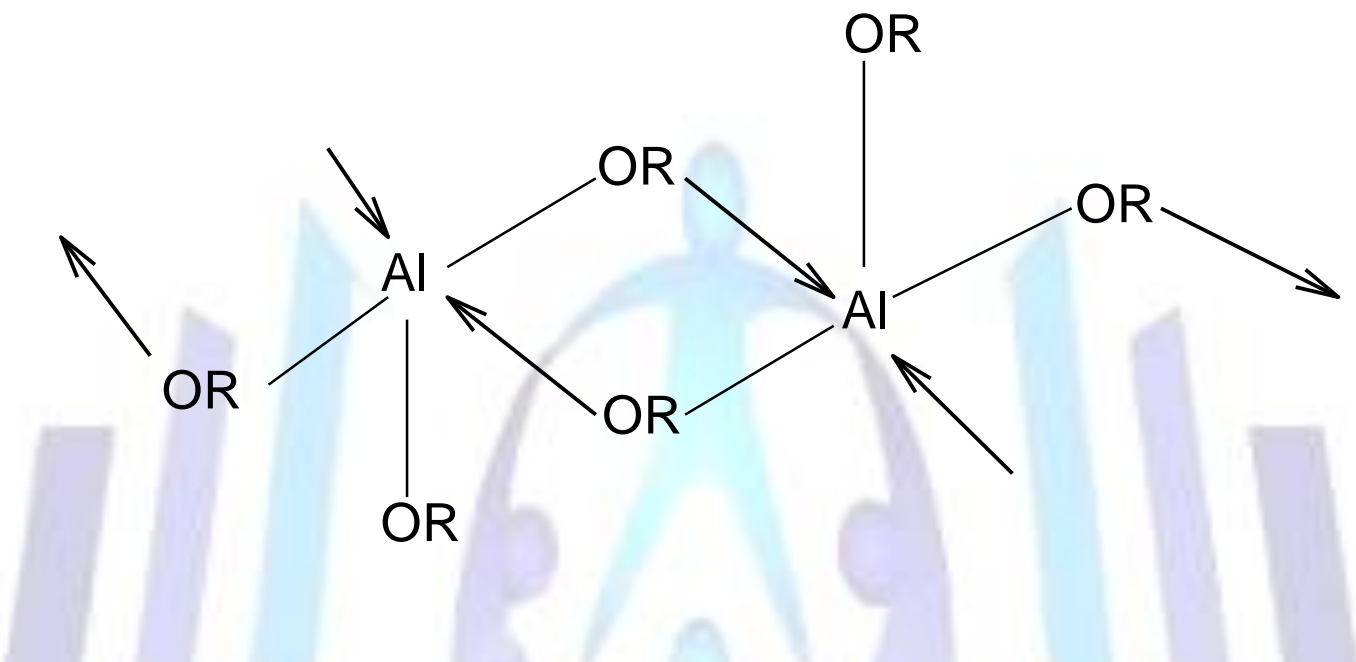

It has been also observed that the bands appeared due to bridged alkoxide groups are strong as compared to those of terminal alkoxide groups. However, the relative intensity of the bands due to bridged alkoxide groups decreases as the size of alkyl group in the alcohol increases thereby indicating that as group became bulky, bridging decreases due to stearic hinderance i.e. intensity of the bridged alkoxide groups decreases as number of carbon atoms increases.

\section{(b) Coordination Compounds of Aluminium Alkoxides:}

The parent aluminium(III) alkoxides prepared by the electrochemical methods have been refluxed with 2,2'-bipyridyl and 1.10-phenanthroline in polar as well as in non polar solvents like methanol, ethanol, benzene and acetonitrile for several hours in order to prepare coordination compounds of these alkoxides. The elemental analysis and infrared spectra of these products, however, reveal that ligand molecules could not rapture the alkoxy bridges in aluminium alkoxides to form their coordination compounds. Therefore, it was thought worthwhile that the ligand should be added before these metal alkoxides get polymerized. So, $1.0 \mathrm{~g}$ of the ligand has been added to alcohol in addition to the supporting electrolyte $\left(\mathrm{Bu}_{4} \mathrm{NCl}\right)$. The solution was then electrolyzed at aluminium anode by applying the similar conditions of parent aluminium(III) alkoxides. Aluminium contents in the electrochemical products correspond to the molecular formula $\mathrm{Al}(\mathrm{OR})_{3}$.L, showing 1:3:1 stoichiometry of aluminium, alcohol and ligand respectively.

The reaction scheme for this is given as:

At Inert Platinum cathode:

$$
3 \mathrm{ROH}+3 \mathrm{e}^{-} \longrightarrow 3 \mathrm{RO}^{-}+3 / 2 \mathrm{H}_{2}
$$

At Sacrificial Aluminium anode: $3 \mathrm{RO}^{-}+\mathrm{Al}_{(+)}+\mathrm{L} \longrightarrow \mathrm{Al}(\mathrm{OR})_{3} \mathrm{~L}+3 \mathrm{e}^{-}$

Infra red spectra of these compounds exhibit characteristic $\mathrm{v}(\mathrm{C}-\mathrm{O}) \mathrm{Al}$ bands at $1145-975 \mathrm{~cm}^{-1}$ and $\mathrm{v}(\mathrm{Al}-\mathrm{O})$ bands at 610 $460 \mathrm{~cm}^{-1}$. Infrared spectra of these compounds reveal that the $\mathrm{v}(\mathrm{C}-\mathrm{O}) \mathrm{Al}$ bands appear in a slightly higher region as compared to the parent alkoxides. There are present two or three absorption bands in the region of $1625-1400 \mathrm{~cm}^{-1}$ due to ligand molecules[22] which were absent in the infrared spectra of the parent aluminium(III) alkoxides. These bands can be assigned to $v(C-C)$ and $v(C-N)$ stretching modes of ligand molecules, thereby confirming that the ligand molecule has been added. Microanalysis (carbon, hydrogen and nitrogen) also show that the ligand molecule has been added (Table-1) and conforms to general formula $\mathrm{Al}(\mathrm{OR})_{3} \mathrm{~L}$.

Presence of the bands due to the bridged alkoxy groups in the infrared spectra, high melting point and insoluble behavior in various organic solvents of present adducts indicate their polymeric nature like their parent aluminium alkoxides.

Current efficiencies of these systems have also been determined and are summarized in Table-1. It has been observed that current efficiency of all these systems is quite high except for hexan-1-ol and heptan-1-ol systems. High current efficiencies of all these systems show that the reactions leading to the formation of aluminium(III) alkoxides and their coordination compounds are the predominant reactions of these systems. Current efficiencies of hexan-1-ol and 
heptan-1-ol systems have been determined at different intervals of time in order to throw light on the reason of low current efficiencies. All the data are recorded in Table-2. Perusal of Table-2 reveals that the current efficiencies are quite high initially but decreases as time of electrolysis increases. The decrease in current efficiencies with time is due to the reason that the products formed in these systems form a protective layer on the electrode surface (aluminium anode) and thus inhibit the further dissolution of metal and hence act as corrosion inhibitors[23].

This technique is simple, direct and one pot method to prepare polymeric aluminium(III) alkoxides and their coordination compounds and can be viable for the commercial preparation of these compounds.

Acknowledgements: We wish to express our sincere thanks to UGC (New Delhi) for the financial support in the form of Major Research Project.

Table-1

Electrolysis Characteristics, analytical and other related data of electrolytic products of alcohol and ligand system at Aluminium anode ;( Potential: 50V, Current in coulombs $=720$ )

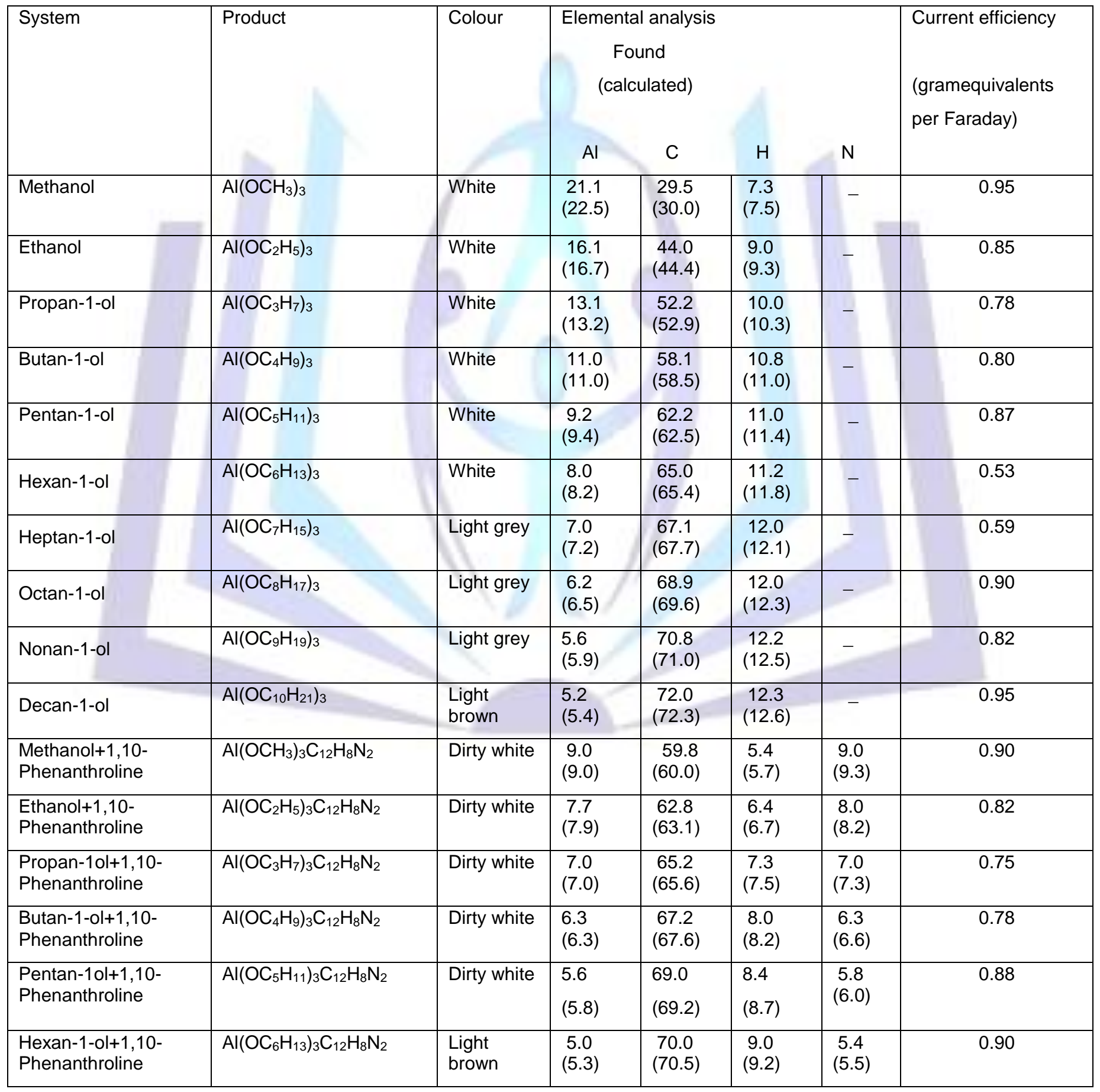




\begin{tabular}{|c|c|c|c|c|c|c|c|}
\hline $\begin{array}{l}\text { Heptan-10l+1,10- } \\
\text { Phenanthroline }\end{array}$ & $\mathrm{Al}\left(\mathrm{OC}_{7} \mathrm{H}_{15}\right)_{3} \mathrm{C}_{12} \mathrm{H}_{8} \mathrm{~N}_{2}$ & $\begin{array}{l}\text { Light } \\
\text { brown }\end{array}$ & $\begin{array}{c}4.6 \\
(4.9)\end{array}$ & $\begin{array}{l}71.1 \\
(71.7)\end{array}$ & $\begin{array}{c}9.5 \\
(9.6)\end{array}$ & $\begin{array}{l}5.0 \\
(5.1)\end{array}$ & 0.92 \\
\hline $\begin{array}{l}\text { Octan-1-ol+1,10- } \\
\text { Phenanthroline }\end{array}$ & $\mathrm{Al}\left(\mathrm{OC}_{8} \mathrm{H}_{17}\right)_{3} \mathrm{C}_{12} \mathrm{H}_{8} \mathrm{~N}_{2}$ & $\begin{array}{l}\text { Light } \\
\text { brown }\end{array}$ & $\begin{array}{c}4.4 \\
(4.5)\end{array}$ & $\begin{array}{c}72.5 \\
(72.7)\end{array}$ & $\begin{array}{l}9.8 \\
(9.9)\end{array}$ & $\begin{array}{c}4.5 \\
(4.7)\end{array}$ & 0.93 \\
\hline $\begin{array}{l}\text { Nonan-10l+1,10- } \\
\text { Phenanthroline }\end{array}$ & $\mathrm{Al}\left(\mathrm{OC}_{9} \mathrm{H}_{19}\right)_{3} \mathrm{C}_{12} \mathrm{H}_{8} \mathrm{~N}_{2}$ & $\begin{array}{l}\text { Light } \\
\text { brown }\end{array}$ & $\begin{array}{l}4.0 \\
(4.2)\end{array}$ & $\begin{array}{c}73.4 \\
(73.5)\end{array}$ & $\begin{array}{c}10.1 \\
(10.2)\end{array}$ & $\begin{array}{l}4.2 \\
(4.4)\end{array}$ & 0.89 \\
\hline $\begin{array}{l}\text { Decan-1-ol+1,10- } \\
\text { Phenanthroline }\end{array}$ & $\mathrm{Al}\left(\mathrm{OC}_{10} \mathrm{H}_{21}\right)_{3} \mathrm{C}_{12} \mathrm{H}_{8} \mathrm{~N}_{2}$ & $\begin{array}{l}\text { Light } \\
\text { brown }\end{array}$ & $\begin{array}{l}3.8 \\
(4.0)\end{array}$ & $\begin{array}{l}74.0 \\
(74.3)\end{array}$ & $\begin{array}{c}10.1 \\
(10.5)\end{array}$ & $\begin{array}{l}3.8 \\
(4.1)\end{array}$ & 0.80 \\
\hline $\begin{array}{l}\text { Methanol + } \\
\text { 2,2' -bipyridyl }\end{array}$ & $\mathrm{Al}\left(\mathrm{OCH}_{3}\right)_{3} \mathrm{C}_{10} \mathrm{H}_{8} \mathrm{~N}_{2}$ & Light pink & $\begin{array}{c}9.5 \\
(9.8)\end{array}$ & $\begin{array}{c}56.4 \\
(56.5)\end{array}$ & $\begin{array}{c}6.1 \\
(6.1)\end{array}$ & $\begin{array}{l}99.8 \\
(10.1)\end{array}$ & 0.85 \\
\hline $\begin{array}{l}\text { Ethanol + } \\
\text { 2,2' -bipyridyl }\end{array}$ & $\mathrm{Al}\left(\mathrm{OC}_{2} \mathrm{H}_{5}\right)_{3} \mathrm{C}_{10} \mathrm{H}_{8} \mathrm{~N}_{2}$ & Light grey & $\begin{array}{c}8.0 \\
(8.5)\end{array}$ & $\begin{array}{l}60.0 \\
(60.3)\end{array}$ & $\begin{array}{l}7.0 \\
(7.2)\end{array}$ & $\begin{array}{l}8.2 \\
(8.8)\end{array}$ & 0.88 \\
\hline $\begin{array}{l}\text { Propan-1-ol+ } \\
2,2 \text { '-bipyridyl }\end{array}$ & $\mathrm{Al}\left(\mathrm{OC}_{3} \mathrm{H}_{7}\right)_{3} \mathrm{C}_{10} \mathrm{H}_{8} \mathrm{~N}_{2}$ & Light grey & $\begin{array}{l}7.3 \\
(7.5)\end{array}$ & $\begin{array}{c}63.2 \\
(63.3)\end{array}$ & $\begin{array}{l}7.9 \\
(8.0)\end{array}$ & $\begin{array}{l}7.3 \\
(7.8)\end{array}$ & 0.92 \\
\hline $\begin{array}{l}\text { Butan-1-ol+ } \\
\text { 2,2'-bipyridyl }\end{array}$ & $\mathrm{Al}\left(\mathrm{OC}_{4} \mathrm{H}_{9}\right)_{3} \mathrm{C}_{10} \mathrm{H}_{8} \mathrm{~N}_{2}$ & Grey & $\begin{array}{l}6.4 \\
(6.7)\end{array}$ & $\begin{array}{l}65.3 \\
(65.6)\end{array}$ & $\begin{array}{c}8.2 \\
(8.7)\end{array}$ & $\begin{array}{c}6.2 \\
(6.9)\end{array}$ & 0.91 \\
\hline $\begin{array}{l}\text { Pentan-1-ol+ } \\
\text { 2,2'-bipyridyl }\end{array}$ & $\mathrm{Al}\left(\mathrm{OC}_{5} \mathrm{H}_{11}\right)_{3} \mathrm{C}_{10} \mathrm{H}_{8} \mathrm{~N}_{2}$ & $\begin{array}{l}\text { Light } \\
\text { brown }\end{array}$ & $\begin{array}{l}5.9 \\
(6.1)\end{array}$ & $\begin{array}{c}67.2 \\
(67.5)\end{array}$ & $\begin{array}{c}9.0 \\
(9.2)\end{array}$ & $\begin{array}{l}6.0 \\
(6.3)\end{array}$ & 0.95 \\
\hline $\begin{array}{l}\text { Hexan-1-ol+ } \\
\text { 2,2'-bipyridyl }\end{array}$ & $\mathrm{Al}\left(\mathrm{OC}_{6} \mathrm{H}_{13}\right)_{3} \mathrm{C}_{10} \mathrm{H}_{8} \mathrm{~N}_{2}$ & Grey & $\begin{array}{l}5.3 \\
(5.5)\end{array}$ & $\begin{array}{l}69.0 \\
(69.1)\end{array}$ & $\begin{array}{c}9.5 \\
(9.7)\end{array}$ & $\begin{array}{l}5.3 \\
(5.7)\end{array}$ & 0.76 \\
\hline $\begin{array}{l}\text { Heptan-1-ol+ } \\
\text { 2,2'-bipyridyl }\end{array}$ & $\mathrm{Al}\left(\mathrm{OC}_{7} \mathrm{H}_{15}\right)_{3} \mathrm{C}_{10} \mathrm{H}_{8} \mathrm{~N}_{2}$ & Grey & $\begin{array}{c}5.0 \\
(5.1)\end{array}$ & $\begin{array}{c}70.2 \\
(70.4)\end{array}$ & $\begin{array}{l}9.8 \\
(10.0)\end{array}$ & $\begin{array}{l}5.0 \\
(5.3)\end{array}$ & 0.73 \\
\hline $\begin{array}{l}\text { Octan-1-ol+ } \\
2,2^{\prime} \text {-bipyridyl }\end{array}$ & $\mathrm{Al}\left(\mathrm{OC}_{8} \mathrm{H}_{17}\right)_{3} \mathrm{C}_{10} \mathrm{H}_{8} \mathrm{~N}_{2}$ & Dark grey & $\begin{array}{l}4.6 \\
(4.7)\end{array}$ & $\begin{array}{l}71.0 \\
(71.5)\end{array}$ & $\begin{array}{c}10.0 \\
(10.3)\end{array}$ & $\begin{array}{l}4.6 \\
(4.9)\end{array}$ & 0.85 \\
\hline $\begin{array}{l}\text { Nonan-1-ol+ } \\
\text { 2,2'-bipyridyl }\end{array}$ & $\mathrm{Al}\left(\mathrm{OC}_{9} \mathrm{H}_{19}\right)_{3} \mathrm{C}_{10} \mathrm{H}_{8} \mathrm{~N}_{2}$ & Grey & $\begin{array}{c}4.1 \\
(4.4)\end{array}$ & $\begin{array}{l}72.3 \\
(72.5)\end{array}$ & $\begin{array}{c}10.3 \\
(10.6)\end{array}$ & $\begin{array}{l}4.4 \\
(4.6)\end{array}$ & 0.88 \\
\hline $\begin{array}{l}\text { Decan-1-ol+ } \\
\text { 2,2'-bipyridyl }\end{array}$ & $\mathrm{Al}\left(\mathrm{OC}_{10} \mathrm{H}_{21}\right)_{3} \mathrm{C}_{10} \mathrm{H}_{8} \mathrm{~N}_{2}$ & $\begin{array}{l}\text { Dark } \\
\text { brown }\end{array}$ & $\begin{array}{l}3.9 \\
(4.1)\end{array}$ & $\begin{array}{l}73.2 \\
(73.4)\end{array}$ & $\begin{array}{c}10.6 \\
(10.8)\end{array}$ & $\begin{array}{c}4.2 \\
(4.3)\end{array}$ & 0.82 \\
\hline
\end{tabular}

Table-2

Current efficiencies of electrochemical reactions of hexan-1-ol and heptan-1-ol at aluminium anode at different intervals of time.

\begin{tabular}{|l|l|l|}
\hline Alcohol & Time(hours) & $\begin{array}{l}\text { Current efficiency } \\
\text { (gram equivalents per Faraday) }\end{array}$ \\
\hline Hexan-1-ol & 1.0 & 0.92 \\
& 1.5 & 0.78 \\
& 2.0 & 0.53 \\
\hline Heptan-1-ol & 1.0 & 0.94 \\
& 1.5 & 0.83 \\
& 2.0 & 0.59 \\
\hline
\end{tabular}




\section{References:}

[1]Rehan,H.A.2003.Polymer International.52:218.

[2]Bell,N.A., Clegg,W. 2000.Inorg.Chim. Acta.220.

[3]Xue Jun Wu, Feng Znu. Cheng Mu, Yongqi Liang, LiftenXu, Oingwei Chen, Ruizhi

Chen and DongshengXu.2010. Coordination Chemistry Reviews.254:1135.

[4]Venkata,S.M., and Sharma,N.P.2003.Pharmabioworld.1(2):101.

[5] Fauzi, F., Diso, D.G., Echendu,O.K., Purandare,Y.,Burton,R., and Dharmadasa, I.M. 2013.Semicond. Sci. Technol. 28(4):045005.

[6] Bradley, D.C., Mehrotra,R.C., and Gaur,D.P. 1978.Metal AlkoxidesAcademic Press. New York.

[7]Banait,J.S.,Deol,S.K., and Singh,B.1990. Synth. React. Inorg. Met.- Org. Chem. 20(10):1331.

[8]Singh, B., Bala, K., Kaur, G., and Singh, S. 2013.ChemSci Trans. 2(1):222

[9]Banait,J.S., Singh,B., and Kaur,H.2007. PortugaliaeElectrochimicaActa.25:435.

[10]Banait,J.S., Singh,B., and Rala,S.2009.J.IndianChem.Soc. 86:416.

[11] Singh, B., and Kaur, H.2008.J.IndianChem.Soc.85:849.

[12]Singh, B., and Bala,K.2011.J. Indian Chem Soc. 88:271.

[13]Singh,B., and Kaur,H.2012.E-Journel of Chemistry.2012, 9(1): 381.

[14]Hai-ping Yang, Sheng-hai Yang et. al. 2011. Science Direct.21:179.

(15) Vogel's, “Text book of Quantitative Chemical Analysis”, Longman group UK, Ltd, 1989.

[16] Sheng-hai Yang, Ya-nan Cal et. al.2009.Science Direct. 19(6):1504.

[17]Malhotra, K.C., and Martin,R.L.1982.J. Organometal. Chem.239:159.

[18] Said, F.F., and Tuck, D.G.1982. Inorg. Chem. Acta. 159:1.

[19] Brubaker, C.H., and Nicoles, M.1965. J.Inorg. nucl. Chem. 27:59.

[20] Barraclough, C. G., Bradley, D.C., Lewis J and Thomas I.M.1967.J. Chem. Soc. 20:2351.

[21] Bradley, D.C., and Westlake, A.H.1965. Proc. Symp. Co-ord. Chem.,Tinhany Hungary Hungaria Acad Sci Budapest.309.

[22] Dyre, J.R., 1978. "Applications of Absorption Spectroscopy of Organic Compounds", Prentice Hall of India Pvt. Ltd, New Delhi.

[23] Banait, J.S., Singh, B., and Rala,S. 2007. J.IndianChem.Soc. 84:135. 